\title{
Plant responses to climate and relationships with pasture persistence
}

\author{
D.F. CHAPMAN ${ }^{1}$, G.R. EDWARDS ${ }^{2}$ and Z.N. NIE ${ }^{3}$ \\ ${ }^{1}$ DairyNZ, Lincoln, New Zealand \\ ${ }^{2}$ Agriculture and Life Sciences Faculty, Lincoln University, Lincoln, New Zealand \\ ${ }^{3}$ Department of Primary Industries Victoria, Hamilton, Australia \\ david.chapman@dairynz.co.nz
}

\begin{abstract}
Relationships between climatic factors and persistence of grazed perennial ryegrass and white clover pastures in New Zealand are reviewed from an ecophysiological perspective. 'Persistence' is defined in terms of physical survival of plants of sown cultivars: the effects of climate on plant populations are considered. Substantial information is available on the population dynamics of perennial ryegrass and white clover in different climatic environments, particularly on the influence of drought on populations. Substantial, direct negative effects of drought on the density of perennial ryegrass tillers and white clover stolons have been recorded, though populations have generally recovered after release from drought conditions. Otherwise, the effects of climaterelated resource limitations on population size are more likely to be interactive, working in concert with other factors such as management, soil fertility and insect pest challenges to limit the capacity of homeostatic responses to restore the optimal (for long term survival) balance between above- and below-ground resources. The relative extent to which more recent cultivars of perennial ryegrass are able to tolerate multiple, simultaneous resource limitations compared to older cultivars (with different phenotype) is considered, but there is little direct evidence on this matter. Issues that should be considered in future pasture persistence research are identified and discussed. One of these concerns is the persistence of trait expression in cultivars bred for specific traits. More research on this topic is warranted, since molecular plant breeding techniques are strongly based on trait manipulation, and genotype $\mathrm{x}$ environment interactions can be expected in the spatially and temporally variable environment of grazed pastures.
\end{abstract}

Keywords: drought, ecology, plant breeding, ryegrass, white clover

\section{Introduction}

How can we best make sense of the relationships between climatic factors and the persistence of pastures? There are many possible interactions, and multiple possible outcomes of those interactions.
Besides the principal climatic factors that influence plant growth (temperature, moisture, radiation), and the genetic variability that exists in any population of pasture plants, we must also account for competition between plants (both inter-specific and intra-specific), abiotic stresses associated with the soil environment or pests and diseases, multi-trophic interactions such as those occurring between plants and micro-organisms (most notably fungal endophytes in grasses), and the management of the pasture.

Then there is the question of what is meant by the term "persistence." When a farmer sows a new pasture, there are usually associated expectations (implicit or explicit) of how that pasture will perform. These expectations are usually framed in terms of the yield of the pasture: it is natural to expect that a newly-sown pasture will yield better than the pasture it replaces, and that the improved yield will be sustained over several years (if sown to perennial species). When these expectations are not met, it is important to resolve the causes of under-performance. In many cases, the causes may be related to failure of plants of the sown species to survive, resulting in invasion of the pasture by other species with lower yield potential. In other cases, newly-sown species may remain abundant in the pasture, but their growth may be limited by factors such as adverse climate conditions or inappropriate management. Reduced yield is the outcome in both cases, but the first instance has to do with issues of persistence of the sown species, whereas the second instance is attributable to factors that limit the yield potential of the sown species. Solutions to the problem will differ between these two situations, so it is important to distinguish clearly between them.

Here we are concerned with persistence, which we define (after Parsons et al.2011) in terms of the continued physical presence of plants of the sown species in the pasture. We do, however, use information on pasture yield, and the components of yield, to set some of the background relating to plant-environment interactions. The aim of this paper is to briefly review how climatic factors influence the persistence of pastures sown to perennial ryegrass (Lolium perenne) and white clover 
(Trifolium repens), and grazed by sheep or cattle. We approach this from an ecophysiological perspective and propose that, while extreme events can deplete perennial ryegrass and white clover populations, they are capable of recovery and therefore climate effects on persistence are most likely to be the result of interactions with other factors that influence plant function, e.g., grazing management, soil fertility, or pest challenges (see also Clark 2011). We discuss this proposition later in the paper.

\section{Plant responses to their environment}

Addressing problems of persistence, as it is defined here, requires a focus on factors operating at the individual plant level that might compromise plant survival. Variability in the climatic environment is clearly one such factor. A useful concept in understanding how plants respond to changes in their environment is that of homeostatic compensation. This rests on the notion that, for a given plant genotype, growth and long-term survival is greatest when a certain balance of aboveand below-ground growth resources is acquired from the environment. Homeostatic compensation sustains that combination of resources (Lambers et al. 1998). When the rate of supply of one or more growth resources is disrupted, a suite of responses will result such that the optimal (for survival) balance between above- and below-ground resources can be restored. The nature of the response is related to the fundamental growth strategy of species. For instance, plants that have evolved in nutrient-rich environments tend to compete strongly for light through high relative growth rates and show rapid and substantial changes in root properties, such as their root mass fraction, when the supply of below-ground resources (nutrients, or water) is restricted (Chapin 1980). Perennial ryegrass and white clover are examples of such species. Conversely, plants that have evolved in nutrient-poor environments maintain high root mass fraction and conserve more resources (carbohydrates, proteins) in plant storage sites to support growth during prolonged periods of low resource availability. 'Low fertility tolerant' weed species found in many New Zealand grassland regions conform to this strategy. Plant strategies have been documented extensively in the ecological literature, and these concepts have also been applied to the development of improved pasture cultivars (e.g., Campbell 1990).

Responses to changes in the availability of growth resources operate at different time scales through different processes. The dominant response(s) will depend on the type and strength of the resource limitation encountered. Short-term fluctuations in resource supply, or moderate shortages, trigger acclimation responses which operate mainly at the level of cell and organ, via biochemical and physiological pathways. Adaptive responses occur over longer time scales and/or in response to more severe limitations, and operate mainly at the level of organ and whole plant. They are usually seen when acclimation responses are insufficient to restore the balance of above- and below-ground resources, and they allow plants to avoid or tolerate the resource limitation. For example, avoidance mechanisms that allow plants to survive severe soil moisture limitations include increased water uptake from deeper and/or more-dense root systems (eg McWilliam \& Kramer 1968, Volaire \& Thomas 1995), ability to extract water from the soil matrix at low water potentials (eg Volaire \& Lelievre 2001), and reduction of water loss through early maturity and leaf senescence (e.g., Volaire \& Lelievre 1997). Tolerance mechanisms include lower lethal hydration levels in meristematic tissues (young meristems are more tolerant of dehydration than old meristems, Barlow et al. 1980), ability to tolerate osmotic potential as low as $-7 \mathrm{MPa}$, and adjustment of osmotic potential through the accumulation of fructans and dehydrins in meristematic cells that help stabilise cell walls and membranes under severe water stress (Hoekstra et al. 2001) (Fig. 1).

The total plant response to resource limitation may therefore be a combination of both short-term acclimation and longer-term adaptation. Edwards and Chapman (2011) develop these concepts further, using the specific example of acclimation and adaptation to defoliation.

\section{Relevance to perennial ryegrass and white clover}

Here we consider the responses of perennial ryegrass and white clover to climate factors, using yield and yield components as indicators of the resource supply rates that best suit the long-term survival of these species. When climatic conditions fall outside this envelope, tolerance or avoidance mechanisms will be important for plant survival so we also briefly discuss the adaptive capacity of perennial ryegrass and white clover, especially with regard to soil moisture deficits.

The first ecotypes of perennial ryegrass and white clover introduced into New Zealand originated from the UK, where the moist, cool-temperate climate and organic soils likely selected for relatively high growth rates in the presence of adequate supplies of nutrients. Both species have high tissue turnover rates and are renowned for their ability to resist defoliation through both tolerance and avoidance responses. These features make them extremely well-suited to grazed pasture systems in temperate climates with moderate-high rainfall, as found widely throughout New Zealand.

Temperature and irradiance responses 
Temperature has a strong effect on plant growth, through its control over the rate of biochemical and developmental processes. The optimum temperature for leaf growth in perennial ryegrass is $18^{\circ} \mathrm{C}$ to $20^{\circ} \mathrm{C}$ (Mitchell 1956), therefore increasing temperature up to approximately $20^{\circ} \mathrm{C}$ should result in higher leaf appearance and expansion rates in perennial ryegrass. Growth responses to changes in irradiance are seen in the range $10^{\circ} \mathrm{C}$ to $30^{\circ} \mathrm{C}$ (Mitchell 1953). Hunt \& Halligan (1981) reported growth responses to irradiance level that followed saturation-type kinetics, and an interaction between temperature and irradiance response. Near-maximum growth rates were sustained between $7^{\circ} \mathrm{C}$ and $20^{\circ} \mathrm{C}$ through compensation between leaf area and photosynthetic rate, but growth clearly declined above $30^{\circ} \mathrm{C}$.

White clover responds similarly to perennial ryegrass to variation in light and temperature (Parsons \& Chapman 2000). Leaf appearance rate is similar for the two species across the temperature range $10^{\circ} \mathrm{C}$ to $20^{\circ} \mathrm{C}$. The phyllochron $\left({ }^{\circ} \mathrm{C} \mathrm{d}\right.$ leaf ${ }^{-1}$, base temperature $=0^{\circ} \mathrm{C}$ ) for primary stem leaves was calculated by Black et al. (2006) to be $94^{\circ} \mathrm{C} \mathrm{d}$ for white clover and $101{ }^{\circ} \mathrm{C} \mathrm{d}$ for perennial ryegrass. There is evidence to show that white clover growth reaches a maximum at a higher temperature than perennial ryegrass $\left(\mathrm{eg} 25^{\circ} \mathrm{C}\right.$, Crush et al. 2003), and a higher optimum temperature for leaf appearance rate in white clover compared to perennial ryegrass may contribute to this. However leaf appearance is slower in white clover than perennial ryegrass in the range $2^{\circ} \mathrm{C}$ to $5^{\circ} \mathrm{C}$, implying a difference in temperature thresholds for growth (e.g., Chapman et al. 1983). Stolon branching frequency (proportion of branch sites that develop into daughter stolons) appears to decline as temperatures rise above $10^{\circ} \mathrm{C}$ (Beinhart, 1963; Hoglund \& Williams 1984), but this is compensated for by higher rates of leaf appearance and therefore high rates of recruitment of sites from which branches may develop, so that there is a broad range of temperature (up to about $30^{\circ} \mathrm{C}$ ) across which branching of clover stolons is close to maximum (Hart 1987).

\section{Soil moisture availability}

Both perennial ryegrass and white clover are considered to be moderately to poorly adapted to low soil moisture availability (Levy 1970). Water shortage limits leaf appearance, leaf expansion and tiller/branch initiation irrespective of availability of other resources, and largely explains inter-annual variability in pasture growth rate. For example, Radcliffe \& Baars (1990) attributed $60 \%$ of inter-annual variation in total annual herbage accumulation of pasture measured at 20 sites across New Zealand over 5 years to variation in spring and summer rainfall. Given the mild temperatures that prevail across New Zealand pastoral regions, direct, lethal stresses related to climatic factors are more likely to come from low soil moisture availability (drought) than temperature (heat shock or freezing injury, which require temperatures $>35^{\circ} \mathrm{C}$ or $<0^{\circ} \mathrm{C}$ respectively).

Perennial ryegrass and white clover tend to have lower root density in sub-soil horizons relative to other species and therefore have a limited capacity to avoid severe soil moisture deficits by accessing water deep in the soil profile compared with deeper rooting plants such as phalaris (Phalaris aquatica) or tall fescue (Festuca arundinacea) (e.g., Nie et al. 2008), or lucerne (e.g., Brown et al. 2005). Neither species displays endogenous dormancy, often referred to as summer dormancy, which Norton et al. (2009) define as "an endogenously controlled and coupled series of processes comprising the cessation or reduction of leaf growth, the complete or partial senescence of herbage, and in some cases the endogenous dehydration of meristems." These responses are expressed consistently under the environmentally inductive conditions typical of Mediterranean summers and also under non-limiting water conditions (Volaire \& Norton 2006, Norton et al. 2008).

The importance of the qualifier of 'non-limiting' conditions in the preceding sentence is that species with the endogenous dormancy trait will become dormant even when supplied with water in summer. This is generally not the case with perennial ryegrass (e.g., Fig. 2 ) and white clover. During periods of severe moisture deficit, perennial ryegrass enters conditional dormancy where most laminae tissue, and some stem material, dies and apical meristem activity is reduced to very low levels (Silsbury 1964, Volaire et al. 1988). This state differs from endogenous dormancy in that it is rapidly broken if moisture becomes available, for example from a summer rain event. When this occurs, it is mainly dormant tiller buds formed on reproductive stems before the onset of leaf senescence that are stimulated to grow (Silsbury 1964, Biddiscombe 1977, Volaire et al. 1988), leaving them vulnerable to recurrence of soil water deficits, or to defoliation (eg Boschma et al. 2003). Both of these can kill the young tillers and deplete the pool of buds available for re-establishment of the tiller population in the following year, leading to significant issues for persistence of perennial ryegrass in Mediterranean-type environments (e.g., Waller et al. 1999).

Hence, for environments that experience frequent and severe soil moisture limitations, other perennial grass species such as phalaris, tall fescue and cocksfoot are better adapted, and therefore provide good options for better matching plant type with environmental limitations (e.g., Hoglund \& White 1985). The relationship between summer dormancy and survival 
Table 1

Changes over time in the density of perennial ryegrass tillers (no./m2) during the imposition of moisture treatments over summer (28th December - 14th April), and during the autumn recovery period (15th April - 12th July). Treatments were: no rainfall or irrigation ('Stressed') versus irrigated when predicted soil water deficit reached $60 \mathrm{~mm}$ ('Irrigated'). From Barker et al. (1985)

\begin{tabular}{lcccccccc}
\hline & \multicolumn{3}{c}{ Treatment period } & & \multicolumn{2}{c}{ Recovery period } \\
\cline { 2 - 5 } Treatment & 29 Dec & $3 \mathrm{Feb}$ & $17 \mathrm{Mar}$ & $14 \mathrm{Apr}$ & & 31 May & $12 \mathrm{Jul}$ \\
\hline Stressed & 4720 & 4235 & 2465 & 1970 & & 4485 & 6255 \\
Irrigated & 4235 & 5023 & 3966 & 4071 & & 5422 & 6004 \\
& $\mathrm{~ns}$ & $\mathrm{~ns}$ & $\mathrm{P}<0.05$ & $\mathrm{P}<0.01$ & & ns & ns \\
\hline
\end{tabular}

is well documented for these species in environments such as the medium-high rainfall zones (approximately $550-700 \mathrm{~mm}$ annual average rainfall) of southern Australia (Fig. 2; see also Nie et al. 2008; Nie \& Norton 2009). The idea of exploiting the drought resistance potential of alternative grass species has been around for a very long time (e.g., Hume \& Fraser 1985, Lancashire 1985), and remains a legitimate one provided species are correctly matched to site-specific environmental conditions.

An option that should be promoted to improve pasture production and persistence within dryland farming systems is a sown pasture of a drought resistant grass and annual legume, such as subterranean clover, that uses stored water in spring and completes growth before the onset of summer dry conditions. In years 6 and 7 of a trial in dryland Canterbury, cocksfootsubterranean clover pastures yielded 9.8 to 11.2 t DM/ ha/y whereas ryegrass-white clover pastures yielded 6.5 to 8.2 t DM/ha/y (Mills \& Moot 2010). In year 7 , the sown grass contributed $40 \%$ of total $\mathrm{DM}$ in cocksfoot-subterranean clover pasture but only $19 \%$ in the ryegrass-white clover pasture (Mills 2010).

\section{Climate factors and plant survival}

The preceding sections describe perennial ryegrass and white clover as being well-adapted to regions experiencing relatively mild temperatures (range $10^{\circ} \mathrm{C}-20^{\circ} \mathrm{C}$ ) where soil moisture deficits are absent, or relatively weak and/or short in duration. This description matches large tracts of land used for pasturebased livestock production in New Zealand. Drought is the obvious direct climatic risk to ryegrass and white clover population survival because both species have limited avoidance/tolerance capacity.

Despite this, tiller and stolon populations can recover from periods of prolonged low soil moisture to reach population densities similar to those present prior to the deficit period once the limitation is lifted. Barker et al. (1985) applied two water treatments over 107 days to perennial ryegrass pasture: 'stressed' (zero
Figure 1 Schematic representation of plant responses to intensifying soil water deficit ( $x$-axis) of a perennial grass that does not possess endogenous dormancy, and relationship to strategies. From Volaire et al. (2009), after Ludlow (1989).

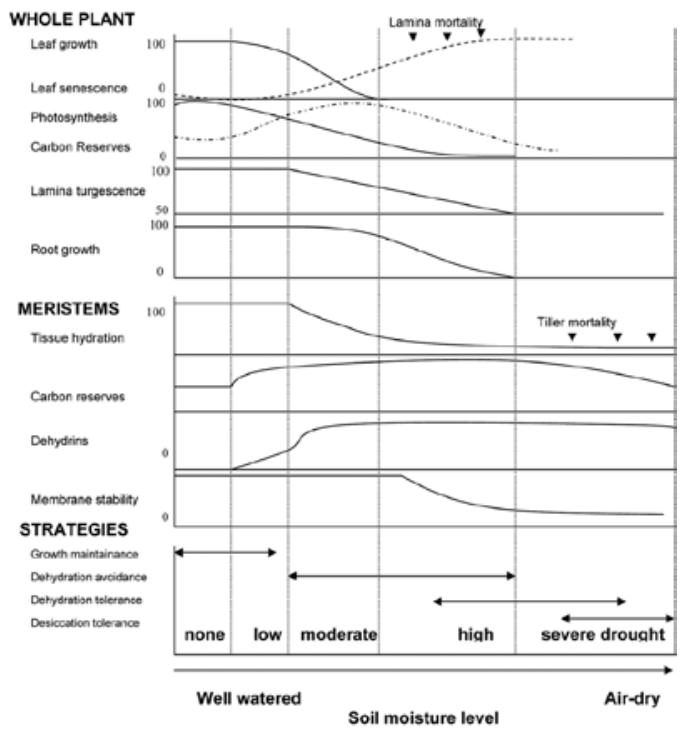

water, under rain-out shelter) versus irrigated (water applied when predicted soil water deficit reached 60 $\mathrm{mm})$. The treatments had very substantial effects on tiller density from late summer until the end of the treatment period (Table 1). During the latter part of summer, tiller appearance rates were $5-14$ tillers $/ \mathrm{m}^{2} /$ day in the stressed treatment while tiller death rates remained high at 34-46 tillers $/ \mathrm{m}^{2} /$ day, resulting in a sharp fall in tiller density. In the irrigated treatment, rates of tiller appearance and death during the same period were relatively high and approximately equal (20-40 tillers $/ \mathrm{m}^{2} /$ day). However, tiller numbers in the stressed treatment recovered quickly after the water limitation treatment finished through rapid rates of new tiller appearance $\left(40-60\right.$ tillers $/ \mathrm{m}^{2} /$ day in previouslystressed pastures compared to $10-30$ tillers $/ \mathrm{m}^{2} /$ day in irrigated pastures, accompanied by similar and low rates of tiller death), such that there was no difference in density between the treatments after 6 weeks of the recovery period (Table 1). Korte \& Chu (1983) and Brock \& Hay (1993) also reported rapid recovery of perennial ryegrass tiller density following removal of soil water deficits, as a result of high tillering rates. Brock \& Hay (1993) further suggested that accelerated tillering following drought is stimulated by high levels of soil mineral $\mathrm{N}$ that accumulate during dry periods.

Barker et al. (1985) also considered the interaction between spring grazing management and summer soil water deficit by cutting swards to either $2.5 \mathrm{~cm}$ or $7.5 \mathrm{~cm}$ residual height in the preceding spring. The 
Figure 2 Relationship between dormancy ratio (number of new shoots per plant : number of live buds per plant, $12 \mathrm{~d}$ after re-watering in late summer; higher ratio indicates lower dormancy) and plant survival 4 years after establishment, for four perennial grass species in Western Australia. From Nie \& Norton (2009), after Biddiscombe et al. (1977).

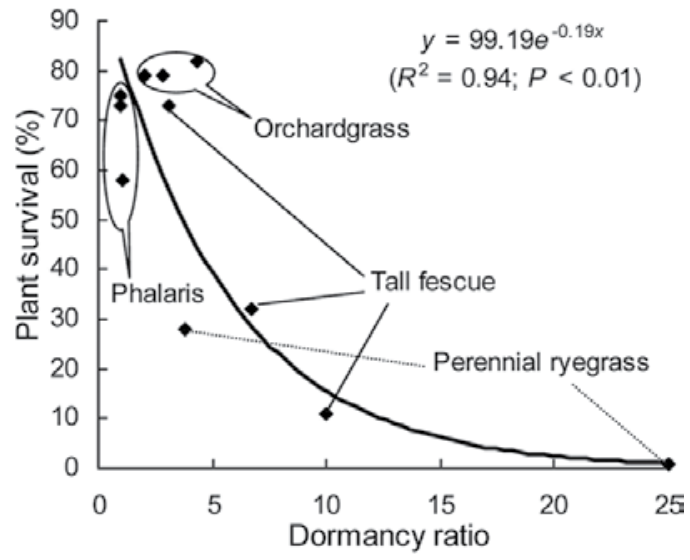

cutting treatments created swards that entered summer with high or low tiller density, respectively. There was no significant treatment interaction for tiller density in autumn: pastures with higher tiller density before drought had a higher tiller density after drought. High density pastures should therefore recover more rapidly after drought but the capacity for compensatory tillering in perennial ryegrass means that tiller density differences can disappear within a few months (e.g., Table 1).

Hay \& Chapman (1984) observed a drop in white clover stolon mass from $280 \mathrm{~kg} \mathrm{DM} /$ ha in early summer to $84 \mathrm{~kg} \mathrm{DM} / \mathrm{ha}$ in autumn after a summer drought in the Wairarapa in early 1983. Continued observations at the site revealed that stolon mass had recovered to pre-drought levels within 18 months. Knowles et al. (2003) observed that clover presence fell to between 40 and $78 \%$ of pre-drought levels at several sites across New Zealand affected by drought (Fig. 3). They also observed substantial recovery of clover presence over the following 18 months, and noted that the rate of recovery of clover was related to the magnitude of the reduction in clover presence. The exception to the recovery trend was in Marlborough, the worst-affected area, where white clover presence fell to only $5 \%$ of pre-drought levels and recovered only slightly during the subsequent 18 months (Fig. 3). Brock \& Hay (1993) observed a sharp fall of $85-90 \%$ in white clover stolon biomass per unit area under rotational grazing following a severe late spring drought in Palmerston North, with recovery to pre-drought levels taking 3 years.
Figure 3 Changes in the frequency occurrence of white clover in pastures sampled repeatedly within different regions prior to, and after, drought during summer 2001. Numbers in the box indicate the percentage of average annual rainfall that was received for each location for the period November 2000 - April 2001, with the values corresponding to (in order from top to bottom): Wairarapa, North Otago, South Canterbury, Mid Canterbury and Marlborough. Redrawn from Knowles et al. (2003).

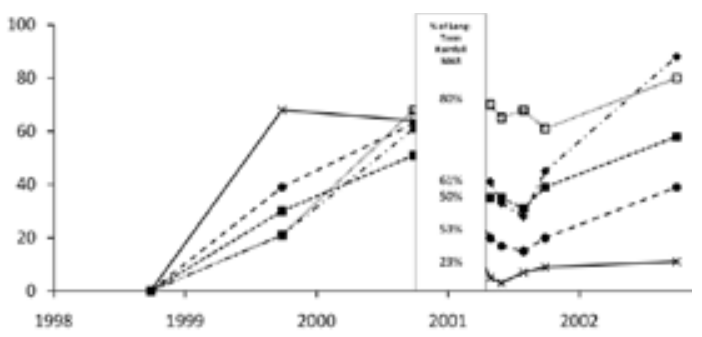

Implications for pasture persistence research

While there is evidence that perennial ryegrass and white clover plant populations can recover from quite severe droughts, and therefore that these species are persistent in most New Zealand grassland environments (see also Daly et al. 1999), farmers frequently report dissatisfaction with persistence of perennial ryegrass/ white clover pastures (e.g., Tozer et al. 2011). Anecdotal information of this sort can be difficult to interpret, however it is possible to propose that something has changed over the past 2-3 decades to create this situation. Potential sources of change include environmental factors, and altered plant phenotype (e.g., Bahmani et al. 2001, 2002) resulting from breeding objectives which have been dominated by increased yield and higher digestibility (Easton et al. 2002) with manipulation of the ryegrass-endophyte association occurring concurrently. 'Environmental factors' are defined here to include management practices such as stocking rate, biotic influences such as the frequency and severity of pest challenges, as well as soil and climatic variables. Stocking rates have increased in at least some of the New Zealand livestock sectors, such as the dairy industry where average cows/ha across the country has increased from around 2.1 in 1980/81 to 2.8 in 2008/09 (LIC 2010), while cow liveweight has also increased over this period leading to a $57 \%$ increase in liveweight/ha (MacDonald et al. 2011). Where increased stocking rate is not accompanied by increased feed supply (from on- or off-farm sources), greater grazing pressure on pastures can be anticipated.

Plant phenotype has also changed, for example through the development of later-flowering perennial ryegrass material, and the release of tetraploid perennial ryegrass cultivars (Charlton \& Stewart 2006). While there is little direct evidence on the matter, it could be argued that modern phenotypes of perennial ryegrass 
are less able to compensate for the effects of resource limitations and, therefore, to sustain the required balance of above- and below-ground resources that maximises their survival in grazing systems operating at higher stocking rates. It is possible that simultaneous occurrence of environmental limitations (climate, soil and management) and/or biotic challenges such as insect pest attack result in different persistence outcomes for modern cultivars compared to older cultivars. As noted above, however, there is little direct evidence on this matter.

In order to better understand and address the persistence 'problem' in New Zealand pastures, future research should consider the following issues:

The extent to which simultaneous occurrence of multiple resource limitations/ challenges affects the ability of perennial ryegrass and white clover to sustain a balance between above- and below-ground resource supply (e.g., Chapin et al. 1987) that optimises their survival in grazed pastures, and the critical interactions with genotype/phenotype. Perennial ryegrass and white clover can withstand single, and often quite severe, climatic limitations, like droughts. However, multiple resource limitations, rather than single limitations, may be the norm in the field. So, for example, if the functioning of perennial ryegrass plants is already disrupted as a result of moisture deficits, what is the additional effect of severe grazing by livestock, or attack by insect pests, on plant survival? Vartha \& Hoglund (1983) alluded to this in their statement: "The cause of pasture deterioration on dryland ....seems more likely to be an effect of autumn over-grazing, particularly if pastures have been attacked by Argentine stem weevil and drought is continuing from summer." However, there appears to have been little systematic investigation into the impacts of simultaneous resource limitations and biotic challenges to plant growth on persistence of pastures in New Zealand, and what this might mean for plant breeding and pasture management objectives.

The extent to which the persistence of specific traits is influenced by variability in the climatic environment, and what further interactions occur between environment and other factors in trait expression. In contrast to the depth and breadth of information available from studies of the population dynamics of perennial ryegrass and white clover (some of which is reviewed above), very few studies have explicitly followed the expression of plant traits held by perennial ryegrass or clover cultivars over seasons, years and/or climatic zones. In perennial ryegrass, breeding objectives have historically been dominated by yield, maturity date, forage quality and pest/disease resistance (Easton et al. 2002). 'Yield' is an outcome of many different traits, and gives us information about the phenotype of the plant without necessarily revealing the specific traits involved (except for ploidy level, which is a specific and, presumably, stable trait). NZPBRA trial data comparing perennial ryegrass cultivars with different maturity dates at multiple sites across New Zealand confirm that maturity date is a stable trait: hence, the rank order of heading date among several cultivars is the same across different climatic environments, even though absolute headings dates may differ (NZPBRA 2010).

More recently, perennial ryegrass cultivars containing higher concentrations of water soluble carbohydrates (WSC) in the leaf lamina have been bred in the United Kingdom (see review by Edwards et al. 2007). These have been grown in Australia and New Zealand, with variable results regarding the expression of the trait. Smith et al. (1998) observed relatively consistent expression of high WSC concentrations across several sites in Australia when two high WSC cultivars were compared to local cultivars. Early field trials in New Zealand revealed only small differences in WSC concentration between Aberdart and the control cultivar Fennema under grazing (Parsons et al. 2004). Subsequent controlled environment studies revealed a significant difference between the high WSC cultivars and Fennema in WSC concentration only after a sustained period of exposure to cold temperatures and short days, conditions akin to late winter - early spring in the UK (Parsons et al. 2004). These results point strongly to the existence of a genotype $\mathrm{x}$ environment $(\mathrm{G} \times \mathrm{E})$ interaction for this trait, the nature of which has not yet been definitively identified. The existence of other $\mathrm{G} \times \mathrm{E}$ interactions affecting specific traits in perennial ryegrass and white clover cannot be ruled out. More information on this issue will become essential as plant breeding becomes more trait-specific, for example through the use of highly targeted molecular breeding techniques.

The extent to which future climate change might alter the balance among factors influencing plant or tiller/stolon survival. For New Zealand, global climate change models predict a general warming trend $\left(1^{\circ} \mathrm{C}\right.$ average rise by 2040), fewer frosts in the south and in the central North Island, more days with a maximum $>25^{\circ} \mathrm{C}$ in the north, and less rainfall in the east coast and north of the North Island, and in coastal parts of Marlborough and Canterbury (NIWA 2008). Collectively, these predictions suggest that summer/ autumn soil moisture deficits for pasture growth will occur more frequently over much of the country, as a result of higher evapotranspiration rates and lower rainfall. This implies that plants could experience resource limitations for longer periods than is currently the case, and that plant survival thresholds could be 
exceeded more often. Less certain is the effect of extreme weather events. These are predicted to occur more frequently (NIWA 2008), increasing the chances that they might coincide with other limitations to plant functioning and result in quite sharp shifts in population structure.

The appropriate design of field studies of persistence to help disentangle the many factors that could potentially contribute to current concerns about pasture persistence and help clarify causal factors. Some suggestions can be drawn from the material covered above. First of all, it is axiomatic that 'persistence' can only be truly assessed over long time periods, so that populations are exposed to the range of inter-annual variability in climate that is present in all New Zealand regions. Population change tends to be episodic, rather than continuous, coinciding with extreme climatic events such as droughts (e.g. Fig. 3), so that population density (however that is measured) cycles unpredictably over time. Quite different conclusions regarding persistence of certain genotypes could be drawn from two similar short-term studies depending on when, during this cyclical pattern, the studies were conducted. Secondly, and related to the point above, it is surely valuable to implement a well-designed experiment simultaneously in more than one region, using common plant and management treatments, so that $\mathrm{G} \times \mathrm{E}$ interactions can be examined. There has been a notable absence of such multi-site agronomic studies in New Zealand in recent years. Plant screening and cultivar merit testing studies do use multiple sites as a standard practice, but they are generally too short-term in nature to shed light on the key persistence issues.

Thirdly, it is very important not to use unsown pastures as the control with which to compare the performance of newly sown pastures. Parsons et al. (2011) elaborate on this, and highlight how it completely confounds effects of genotype with effects of disturbance. It is difficult to see how studies structured this way could provide useful information about persistence. Fourthly, inclusion of older cultivars of perennial ryegrass or white clover that would have been considered as 'industry standards' 2-3 decades ago for specific livestock sectors could help reveal the extent to which changes in plant phenotype in newer material have altered the ability of plants to maintain homeostatic growth in the face of environmental and management challenges. Finally, the inclusion of other species with known ability to tolerate or avoid specific climatic conditions could also help inform the debate about how breeding objectives in ryegrass and white clover may have altered the ability of these species to meet expectations in New Zealand grazing systems.

\section{REFERENCES}

Bahmani, I.; Thom, E.R.; Matthew, C.; Lemaire, G. 2001. Productivity of grazed perennial ryegrass dairy pastures from different ecotypes under nitrogen and irrigation treatments. New Zealand Journal of Agricultural Research 44: 123-133.

Bahmani, I.; Thom, E.R.; Matthew, C.; Lemaire, G. 2002. Flowering propensity of two New Zealand perennial ryegrass cultivars originating from different ecotypes. New Zealand Journal of Agricultural Research 45: 129-137.

Barker, D.J.; Chu, A.C.P.; Korte, C.J. 1985. Some effects of spring defoliation and drought on perennial ryegrass swards. Proceedings of the New Zealand Grassland Association 46: 57-63.

Barlow, E.W.R.; Munns, R.E.; Brady, D.J. 1980. Drought responses of apical meristems. pp 191-205. In: Adaptation of plants to water and high temperature stress. Eds. Turner, N.C.; Kramer, P.J. John Wiley \& Sons, New York.

Beinhart, G. 1963. Effects of environment on meristematic development, leaf area and growth of white clover. Crop Science 3: 209-213.

Biddiscombe, E.F.; Rogers, A.L.; Maller, R.A. 1977. Summer dormancy, regeneration and persistence of perennial grasses in south-western Australia. Australian Journal of Experimental Agriculture and Animal Husbandry 17: 795-801.

Black, A.D.; Moot, D.J.; Lucas, R.J. 2006. Development and growth characteristics of Caucasian and white clover seedlings, compared with perennial ryegrass. Grass and Forage Science 61: 442-453.

Boschma, S.P.; Hill, M.J.; Scott, J.M.; Rapp, G.G. 2003. The response to moisture and defoliation stresses, and traits for resilience of perennial grasses on the Northern tablelands of New South Wales, Australia. Australian Journal of Agricultural Research 54: 903-916.

Brock, J.L.; Hay, R.J.M. 1993. An ecological approach to forage management. pp 837-842. In. Proceedings of the XVII International Grassland Congress:

Brown, H.E.; Moot, D.J.; Pollock, K.M. 2005. Herbage production, persistence, nutritive value and water use of perennial forages grown over 6 years on a Wakanui silt loam. New Zealand Journal of Agricultural Research 48: 423-439.

Campbell, B.D. 1990. Pasture cultivars in ecological perspective. Proceedings of the New Zealand Grassland Association 51: 139-142.

Chapin, F.S. 1980. The mineral nutrition of wild plants. Annual Review of Ecology and Systematics 11: 233-260.

Chapin, F.S.; Bloom, A.J.; Field, C.B.; Waring, R.H. 1987. Plant responses to multiple environmental factors. Bioscience 37: 49-57. 
Chapman, D.F.; Clark, D.A.; Land, C.A.; Dymock, N. 1983. Leaf and tiller growth of Lolium perenne and Agrostis spp. and leaf appearance rates of Trifolium repens in set stocked and rotationally grazed hill pastures. New Zealand Journal of Agricultural Research 26: $159-168$

Charlton, D.; Stewart, A. 2006. Pasture and forage plants for New Zealand. Grassland Research and Practice Series 8: 128 pp.

Clark, D.A. 2011. Changes in pastoral farming practices and pasture persistence - a review. Pasture Persistence. Grassland Research and Practice Series 15: 7-13.

Crush, J.R.; Campbell, B.D.; Caradus, J.R. 1993. Effect of temperature on nitrogen fixation rates in seven white clover cultivars. pp 119-121. In. Proceedings of the XVII International Grassland Congress.

Daly, M.J.; Fraser, T.; Perkins, A.; Moffat, C.M. 1999. Farmer perceptions of reasons for perennial pasture persistence and the relationship of these with management practice, species composition, and soil fertility. Proceedings of the New Zealand Grassland Association 61: 9-15.

Easton, H.S.; Amyes, J.M.; Cameron, N.E.; Green R.B.; Kerr, G.A.; Norriss M.G.; Stewart A.V. 2002. Pasture plant breeding in New Zealand: where to from here? Proceedings of the New Zealand Grassland Association 64: 173-179.

Edwards, G.R.; Chapman, D.F. 2011. Plant responses to defoliation and relationships with pasture persistence. Pasture Persistence. Grassland Research and Practice Series 15: 39-46.

Edwards, G.R.; Parsons, A.J.; Rasmussen, S. 2007. High sugar ryegrasses for dairy systems. pp. 307334. In: Proceedings of the $3^{\text {rd }}$ Australasian Dairy Science Symposium. Eds. Chapman, D.F.; Clark, D.A.; Macmillan, K.L.; Nation, D.P.

Hart, A.L. 1987. Physiology. pp. 125-147. In: White clover. Eds. Baker, M.J.; Williams, W.M. CAB International, Wallingford.

Hay, M.J.M.; Chapman, D.F. 1984. Observations on the distribution of clover stolons in hill swards. Proceedings of the New Zealand Grassland Association 45: 124-130.

Hoekstra, F.A.; Golovina, E.A.; Buitnik, J. 2001. Mechanisms of plant desiccation tolerance. Trends in Plant Science 6: 431-439.

Hoglund, J.H.; White, J.G.H. 1985. Environmental and agronomic constraints in dryland pasture and choice of species. Using Herbage Cultivars. Grassland Research and Practice Series 3: 39-43.

Hoglund, J.H.; Williams, W.M. 1984. Genotypic variation in white clover growth and branching in response to temperature and nitrogen. New Zealand
Journal of Agricultural Research 27: 19-24.

Hume, D.E.; Fraser, T.J. 1985. Establishing and managing recent cultivars in arable dryland pastures. Using Herbage Cultivars. Grassland Research and Practice Series 3: 45-48.

Hunt, W.F.; Halligan, G. 1981. Growth and development responses of perennial ryegrass grown at constant temperature. I. Influence of light and temperature on growth and net assimilation. Australian Journal of Plant Physiology 8: 181-190.

Hunt, W.F.; Thomas, V.J. 1985. Growth and development responses of perennial ryegrass grown at constant temperature. II. Influence of light and temperature on leaf, tiller and root appearance. Australian Journal of Plant Physiology 12: 69-76.

Knowles, I.M.; Fraser, T.J.; Daly, M.J. 2003. White clover: loss in drought and subsequent recovery. Legumes for Dryland Pastures. Grassland Research and Practice Series 11: 37-41.

Korte, C.J.; Chu, A.C.P. 1983. Some effects of drought on perennial ryegrass swards. Proceedings of the New Zealand Grassland Association 44: 211-216.

Lambers, H.; Chapin, F.S. II; Pons, T.L. 1998. Plant physiological ecology. Springer-Verlag, New York. $540 \mathrm{pp}$.

Lancashire, J.A. 1985. Some factors affecting the rate of adoption of new herbage cultivars. Using Herbage Cultivars. Grassland Research and Practice Series 3: 79-87.

Levy, E.B. 1970. Grasslands of New Zealand. Third edition. A.R. Shearer, Government Printer, Wellington. 374 pp.

LIC 2010. New Zealand dairy statistics 2009-10. Livestock Improvement Corporation. $52 \mathrm{pp}$.

Ludlow, M.M. 1989. Strategies of response to water stress. Pp. 269-281. In: Structural and functional responses to environmental stress: Water shortage. Ed. Kreeb, K.H. SPB Academic Publishing, The Hague.

MacDonald, K.A.; Matthew, C.; Glassey, C.B.; McLean, N. 2011. Dairy farm systems to aid persistence. Pasture Persistence. Grassland Research and Practice Series 15: 199-209

McWilliam, J.R. 1968. The nature of the perennial response in Mediterranean grasses. 2. Senescence, summer dormancy and summer survival in Phalaris. Australian Journal of Agricultural Research 19: 397-409.

McWilliam, J.R.; Kramer, P.J. 1968. The nature of the perennial response in Mediterranean grasses. 1. Water relations and summer survival in Phalaris. Australian Journal of Agricultural Research 19: 381-395.

Mills, A.; Moot, D.J. 2010. Annual dry matter, metabolisable yield and nitrogen yields of six dryland pastures six and seven years after establishment. 
Proceedings of the New Zealand Grassland Association 72: 177-184.

Mitchell, K.J. 1953. Influence of light and temperature on the growth and development of ryegrass (Lolium species). 1. Pattern of vegetative development. Physiologia Plantarum 6: 21-46.

Mitchell, K.J. 1956. Growth of pasture species under controlled environment. 1. Growth at various levels of constant temperature. New Zealand Journal of Science and Technology 38A: 203-216.

Nie, Z.N.; Norton, M.R. 2009. Stress tolerance and persistence of perennial grasses: The role of the summer dormancy trait in temperate Australia. Crop Science 49: 2405-2411.

Nie, Z.N.; Miller, S.; Moore, G.A.; Hackney, B.F.; Boschma, S.P.; Reed, K.F.M.; Mitchell, M.; Albertson, T.O.; Clark, S.; Craig, A.D.; Kearney, G.A.; Li, G.D.; Dear, B.S. 2008. Field evaluation of perennial grasses and herbs in southern Australia. 2. Persistence, root characteristics and summer activity. Australian Journal of Experimental Agriculture 48: 424-435.

NIWA 2008. Climate change projections for New Zealand. Accessed 12 ${ }^{\text {th }}$ October 2010. www. niwascience.co.nz/ncc.

Norton, M.R.; Volaire, F.; Fukai, S.; Lelievre, F. 2008. Measurement of summer dormancy in temperate perennial pasture grasses. Australian Journal of Agricultural Research 59: 498-509.

Norton, M.R.; Volaire, F.; Lelievre, F.; Fukai, S. 2009. Identification and measurement of summer dormancy in temperate perennial grasses. Crop Science 49: 2347-2352.

NZPBRA, 2010. National Forage Variety Trials. Data summaries: Perennial ryegrass 1991-2009. Christchurch, New Zealand: New Zealand Plant Breeding and Research Association.

Parsons, A.J.; Chapman, D.F. 2000. Principles of pasture growth and utilisation. pp. 31-89. In: Grass. Its Production and Utilisation. Ed. Hopkins, A. Blackwell Science, Oxford.

Parsons, A.J.; Rasmussen, S.; Xue, H.; Newman, J.A.; Anderson, C.B.; Cosgrove, G.P. 2004. Some high sugar grasses don't like it hot. Proceedings of the New Zealand Grassland Association 66: 265-272.

Parsons, A.J.; Edwards, G.R.; Newton, P.C.D.; Chapman, D.F.; Caradus, J.R.; Rasmussen, S.; Rowarth, J.S. 2011. Past lessons and future prospects: plant breeding for yield and persistence in cool temperate pastures. Grass and Forage Science: in press.

Radcliffe, J.E.; Baars, J.A. 1990. The productivity of temperate grasslands. pp. 7-17. In: Ecosystems of the World. 17B. Managed Grasslands. Ed. Snaydon, R.W. Elsevier, Amsterdam.
Silsbury, J.H. 1964. Tiller dynamics, growth and persistency of Lolium perenne L. and Lolium rigidum Gaud. Australian Journal of Agricultural Research 15: 9-20.

Smith, K.F.; Simpson, R.J.; Oram, R.N.; Lowe, K.F.; Evans, P.M.; Humphreys, M.O. 1998. Seasonal variation in the herbage yield and nutritive value of perennial ryegrass (Lolium perenne L.) cultivars with high or normal water soluble carbohydrate concentrations grown in three contrasting Australian dairy environments. Australian Journal of Experimental Agriculture 38: 821-830.

Tozer, K.N.; Clark, C.A.; Thom, E.R. 2011. Pasture persistence: farmer observations and field measurements. Pasture Persistence. Grassland Research and Practice Series 15: 25-30.

Vartha, E.W.; Hoglund, J.H. 1983. What is the makeup of a dryland pasture? Proceedings of the New Zealand Grassland Association 44: 204-210.

Volaire, F.; Thomas, H. 1995. Effects of drought on water relations, mineral uptake, water soluble carbohydrates accumulation and survival of two contrasting populations of cocksfoot (Dactylis glomerata L.). Annals of Botany 75: 513-524.

Volaire, F.; Lelievre F. 1997. Production, persistence and water soluble carbohydrate accumulation in 21 contrasting populations of Dactylis glomerata L. subjected to severe drought in the south of France. Australian Journal of Agricultural Research 48: 933-944.

Volaire, F.; Lelievre, F. 2001. Drought survival in Dactylis glomerata and Festuca arundinacea under similar rooting conditions in tubes. Plant and Soil 229: 225-234.

Volaire, F.; Thomas, H.; Lelievre, F. 1998. Survival and recovery of perennial forage grasses under prolonged Mediterranean drought. I. Growth, death, water relations and solute content in herbage and stubble. New Phytologist 140: 439-449.

Volaire, F.; Norton, M.R. 2006. Summer dormancy in temperate perennial grasses. Annals of Botany 98: 927-933.

Volaire, F.; Norton, M.R.; Lelievre, F. 2009. Summer drought survival strategies and sustainability of perennial temperate forage grasses in Mediterranean areas. Crop Science 49: 2386-2392.

Waller, R.A.; Sale, P.W.G.; Saul, G.R.; Quigley, P.E.; Kearney, G.A. 1999. Tactical versus continuous stocking for persistence of perennial ryegrass (Lolium perenne L.) in pastures grazed by sheep in south-western Victoria. Australian Journal of Experimental Agriculture 39: 265-274. 
